Santa Clara University

Scholar Commons

Environmental Studies and Sciences

College of Arts \& Sciences

8-8-2016

\title{
Hidden costs and deadweight losses: Bundled parking andresidential rents in the metropolitan United States
}

C.J. Gabbe

Santa Clara University, cgabbe@scu.edu

Gregory Pierce

Follow this and additional works at: http://scholarcommons.scu.edu/ess

Part of the Environmental Studies Commons

\section{Recommended Citation}

Gabbe, C. J., \& Pierce, G. (2017). Hidden Costs and Deadweight Losses: Bundled Parking and Residential Rents in the Metropolitan United States. Housing Policy Debate, 27(2), 217-229. https://doi.org/10.1080/10511482.2016.1205647

This Article is brought to you for free and open access by the College of Arts \& Sciences at Scholar Commons. It has been accepted for inclusion in Environmental Studies and Sciences by an authorized administrator of Scholar Commons. For more information, please contact rscroggin@scu.edu. 


\section{Hidden Costs and Deadweight Loss:}

\section{Bundled Parking and Residential Rents in the Metropolitan United States}

Author Information:

C.J. Gabbe, Doctoral Candidate (Corresponding Author)

Department of Urban Planning

UCLA Luskin School of Public Affairs

3250 School of Public Affairs Building

Box 951656

Los Angeles, CA 90095-1656

cgabbe@ucla.edu

Gregory Pierce, Postdoctoral Scholar

UCLA Luskin Center for Innovation

University of California, Los Angeles

3323 School of Public Affairs Building

Los Angeles, CA 90095-1656

gspierce@ucla.edu 


\begin{abstract}
There is a major housing affordability crisis in many American metropolitan areas, particularly for renters. Minimum parking requirements in municipal zoning codes drive up the price of housing, and thus represent an important potential for reform for local policymakers. The relationship between parking and housing prices, however, remains poorly understood. We use national American Housing Survey data and hedonic regression techniques to investigate this relationship. We find that the cost of garage parking to renter households is approximately $\$ 1,700$ per year, or an additional $17 \%$ of a housing unit's rent. In addition to the magnitude of this transport cost burden being effectively hidden in housing prices, the lack of rental housing without bundled parking imposes a steep cost on carless renters - commonly the lowest income households - who may be paying for parking that they do not need or want. We estimate the direct deadweight loss for carless renters to be $\$ 440$ million annually. We conclude by suggesting cities reduce or eliminate minimum parking requirements, and allow and encourage landlords to unbundle parking costs from housing costs.
\end{abstract}

\title{
Keywords
}

Affordability, land use/zoning, prices, regulation, rental housing, transportation, urban planning 


\section{Introduction}

The United States is in the midst of a housing affordability crisis, particularly for urban renters (Joint Center for Housing Studies, 2015). Fast-rising housing prices, especially in coastal metropolitan areas, have been attributed to restrictive land use regulations (Glaeser, Gyourko, \& Saks, 2005; Quigley \& Raphael, 2005). Accordingly, minimum off-street parking requirements, a central component of land use regulation in the United States, warrant detailed study and potential policy reform. In most cities today, developers are required by municipal regulation to provide on-site parking. As a result, the large majority of housing units include "bundled" parking, which refers to parking spaces that are rented or sold in conjunction with a housing unit (McDonnell, Madar, \& Been, 2011). While many households might have chosen to pay for onsite parking in a free market, this proportion is surely significantly lower than what has been mandated. Moreover, the historical effect of minimums and bundled parking effectively hides a transport cost burden in housing prices, leaving households unable or unaware of their ability to choose. Urban policymakers have thus taken an interest in reforming parking regulations and allowing unbundled parking based on social equity and environmental sustainability rationales. A major justification for parking-related policy changes is that existing requirements unnecessarily drive up the price of housing. To date, there are no national estimates of the impact of required parking provision on housing prices. Thus, we ask: what are the effects of parking provision on residential rents in America's cities?

To answer this question, we utilize a nationally representative sample of rental housing units from the 2011 American Housing Survey (AHS). We first outline the existing state of research and the policy rationale for reducing parking regulation, including the case for unbundling parking costs from rental housing costs. We then focus our analysis on garage 
parking, the costliest form of off-street parking (Shoup, 2014). We describe the prevalence of bundled and garage parking across different types of households, housing units, and metropolitan areas. We subsequently build hedonic regression models to estimate the effect of garage parking on residential rents in U.S. metropolitan areas. We find that the cost of garage parking for renters is approximately $\$ 1,700$ per year, and the bundling of a garage space adds about $17 \%$ to a unit's rent. There are about 708,000 households without a car who have a garage parking space. Much of this excess parking supply is due to municipal regulations, not consumer demand, and represents a direct deadweight loss to society estimated to be approximately $\$ 440$ million per year. We argue, however, that this figure represents just the tip of the iceberg when considering the indirect cost of minimum parking requirements. We conclude by suggesting two types of local land use regulatory changes to reduce the high cost burden of parking: (1) cities should reduce or eliminate minimum parking requirements, and (2) cities should allow or encourage landlords to offer unbundled parking options.

\section{Literature review}

We analyze parking policy within the context of broader debates about the impact of land use regulations on the housing affordability crisis taking place in many American cities. We then describe the current state of American parking regulation and provision, and the case for regulatory reform. Lastly, we examine empirical evidence showing minimum parking requirements to be a binding constraint which increases housing prices. 


\section{Land use regulations and housing affordability}

The rise of housing supply limitations has been called "the most important transformation that has happened in the American housing market since the development of the automobile" (Glaeser et al., 2005, p. 20). The mechanisms through which land use regulations may limit housing supply, and increase housing prices, include (1) directly or indirectly reducing density, (2) imposing costly standards on developers, (3) shifting costs from the municipality to developers, and (4) removing land from the developable supply (Deakin, 1989; Levine, 1999). Parking regulation is most closely tied to the first two mechanisms. Minimum parking standards reduce density if land that would otherwise be devoted to buildings is instead devoted to car storage (Manville, 2013). This makes some infill development physically and/or financially infeasible (Farris, 2001; Kennedy, 1995; Landis, Hood, Li, Rogers, \& Warren, 2006). Minimum parking requirements can also be very costly to real estate developers. Along with the opportunity cost of devoting space to parking rather than other land uses, there is a high direct cost of building new parking. Nationally, in 2012, the average cost to build one underground parking space was $\$ 34,000$ and to build an above-ground parking space was $\$ 24,000$ (Shoup, 2014). These costs are ultimately passed on to the consumer, whether they have a car or not (Shoup, 2005).

\section{Regulations and the ubiquity of bundled parking}

The spread of now-ubiquitous municipal parking regulations in the first part of the twentieth century has been well-documented (see Shoup, 2005). Although regulatory approaches vary somewhat by municipality and specific zoning designation, residential parking requirements are commonly based on housing type (e.g., single-family, multi-family) and the size of the 
housing unit (e.g., number of bedrooms) (McDonnell et al., 2011). Minimum parking standards increased over time (Chester, Fraser, Matute, Flower, \& Pendyala, 2015; Shoup, 2005). In Los Angeles County, for example, between 1936 and 1960, the average apartment was required to have one parking space and the typical single-family home was required to have two parking spaces. After 1960, requirements for an average apartment increased to two spaces, and those for single-family homes increased to three spaces (Chester et al., 2015).

Widespread minimum parking requirements have, not surprisingly, resulted in a limited supply of housing options without dedicated parking. Housing without bundled parking has emerged in three main ways. First, housing units built before the 1930s, before off-street parking requirements were adopted as a municipal response to on-street parking shortages, often have no on-site parking (Shoup, 2005). Second, for new housing developments, some cities - including New York, San Francisco, Portland, and now Los Angeles — have recently reduced or eliminated minimum parking requirements in downtowns or other neighborhoods (City of Los Angeles, 2013; Millard-Ball, 2002). San Francisco has even banned the bundling of parking into the monthly rent or sales price of a new housing unit (City of San Francisco, 2013). Third, planning officials sometimes use their discretion to approve zoning variances for development with less parking than required, but getting these variances approved is easier in certain cities than others (Gabbe, 2016; Manville, Beata, \& Shoup, 2013).

Given these limited scenarios, the prevalence of housing without parking is generally low and varies considerably by city and metropolitan area. For example, about $95 \%$ of metropolitan Los Angeles housing units include at least one parking space, while only $63 \%$ of those in metropolitan New York City include one or more parking spaces (Manville et al., 2013). 
Comparing the two central cities reveals an even larger disparity: 90\% of central Los Angeles units but only $31 \%$ of central New York City units have parking.

The case for parking reform

Reforming parking standards is of great interest to planners, policymakers and developers for several reasons. First, high parking requirements reinforce auto-oriented development patterns, hindering cities' sustainability goals (Manville et al., 2013). Second, the supply of parking space necessitated by minimum standards exceeds the demand for parking in many areas, resulting in inefficient land use (Shoup, 2005). Third - and the primary focus of this paper - is that parking standards impose unnecessary costs on renters and buyers, particularly in expensive housing markets (Manville et al., 2013). Ideally, consumers should have a choice as to whether they buy or rent a parking space connected with a housing unit Parking spaces are not necessary housing unit attributes, regulated for health or safety reasons, as are connections to water or sewage service, for example (Shoup, 2005). Rather, parking spaces are residential amenities, similar to on-site storage space, a dishwasher or air-conditioning. Parking provision should be market-driven; developers should have flexibility in how much parking they provide, and housing consumers should have a choice in how much parking they rent or buy.

\section{Minimum parking requirements constrain new development}

Minimum parking requirements are a constraint on new development in some areas. That is, if requirements were lowered or eliminated, real estate developers could consequently reduce the amount of parking they provide (Manville, 2013; McDonnell et al., 2011). A small body of empirical research shows that parking requirements act as a binding constraint, in the context of 
non-residential properties in metropolitan Los Angeles (Cutter \& Franco, 2012), adaptive reuse of commercial properties in downtown Los Angeles (Manville, 2013), new housing developments in London (Li \& Guo, 2014), and in New York City (McDonnell et al., 2011). McDonnell and colleagues (2011), for example, compared the amount of parking required onsite with the amount that developers actually built in Queens, New York. They found that the majority of real estate developers built at the minimum requirements or below (if they were able to get a waiver).

Along with the direct effects of parking requirements, parking regulations also engender several indirect adverse impacts. Studying New York City, Manville et al. (2013) found that a ten percent increase in minimum parking requirements was associated with a five percent increase in vehicle density, a five percent increase in vehicles per capita, six percent reductions in population and housing densities, and a two percent reduction in transit commute share. High parking requirements and bundled parking may even induce higher auto ownership (Manville, (in press)).

Parking is associated with higher housing prices

Several city-specific studies provide empirical estimates of the effect of parking provision on housing costs (Manville, 2013). Scholars have used multivariate techniques to isolate the value of a parking space within the context of a larger bundle of housing attributes. Jia and Wachs (1999) collected data on a sample of 232 property sales in San Francisco to test the relationship between off-street parking and housing prices. They used a hedonic regression model and found that the average single-family unit with off-street parking sold for $12 \%$ higher and the average condo unit with off-street parking sold for $13 \%$ higher than the price of units 
without parking. Manville (2013) studied a sample of buildings in downtown Los Angeles that had been converted to housing after the city passed its Adaptive Reuse Ordinance, which reduced parking requirements for these types of projects in and near downtown L.A. The author regressed the natural log of price on bundled parking, bathroom, year of construction, and other housing attributes. He found that an "apartment with bundled parking is associated with $\$ 200$ more in asking rent, and bundled parking with a condo is associated with a $\$ 43,000$ increase in asking price" (Manville, 2013, p. 12). These articles provide some preliminary evidence regarding the effect of bundled parking on housing prices, but are limited to selected neighborhoods within single cities. Building on these studies, we draw on a national sample of housing units and a more robust set of control variables to assess this relationship and provide the evidence base for unbundling reform across U.S. cities.

\section{Data}

Data for this study are primarily derived from the 2011 American Housing Survey (AHS), a biennial survey sponsored by the U.S. Department of Housing and Urban Development (HUD) and conducted by the U.S. Census Bureau. The AHS is unique because each survey contains both a nationally representative sample of housing units, which are surveyed consistently over time, and an over-sample of housing units from a rotating set of metropolitan areas. The AHS provides weights to ensure that the total sample is representative of the national housing stock, as well as replicate weights to account for variance in single survey estimates. In all calculations reported in this analysis, we follow the guidance of the AHS codebook and employ 160 replicate survey weights using the balanced repeated replicate (BRR) weights command in Stata 13. 
The AHS includes questions on topics including household socioeconomic characteristics, physical housing quality attributes, housing costs and tenancy arrangements, relocation behavior, neighborhood characteristics, and intra- and inter-metropolitan locations (AHS, 2014). We restrict our sample to urban areas of U.S. Census Bureau defined metropolitan statistical areas (MSAs) because there is sufficient demand for land in these areas to make the space needed for parking very costly (Willson, 1995). In the $2011 \mathrm{AHS}$, more than $7 \%$ of all housing units in urban areas do not have bundled parking, compared with less than $2 \%$ of all housing units outside urban areas. Similarly, parking is rarely unbundled for homeowners (less than $3 \%$ ) and is much more prevalent for rental units (nearly 13\%). Moreover, we further restrict our sample to renters in urban areas because these households are experiencing the worst - and worsening - housing cost burdens (Joint Center for Housing Studies, 2015). Using the 2011 AHS micro-data, we can analyze such 38,662 rental units, which are statistically representative of the national urban, rental housing stock.

Our primary outcome of interest in this analysis is annual household rent. We measure this using the variable RENT, which denotes how much is paid by a household at a given time, and FRENT, which denotes the frequency of the rent payment (e.g. weekly, monthly etc.). The RENT variable does not include parking costs if parking is "priced separately" (Econometrica, Inc., 2013, p. 450). As described above, our analysis focuses on the relationship between parking and rent. We focus specifically on garage parking because it is the most expensive type of parking to construct, and the most prevalent form of parking in central, transit-oriented 
neighborhoods. ${ }^{1}$ Nationally, the construction cost of an above-ground structured parking space averages $\$ 24,000$ and an underground space averages $\$ 34,000$ (Shoup, 2014). In the AHS, the variable GARAGE indicates if one or more garage or carport parking spaces is included with the unit rent, and these parking spaces may be located underground or above ground (Econometrica, Inc., 2013). In the remainder of this paper, we refer to these garage and carport spaces as garage spaces for simplicity’s sake.

\section{Modeling approach}

Our approach to modeling parking provision as a determinant of residential rents is based on the conception of a housing unit as a heterogeneous bundle of attributes (Kain \& Quigley, 1975). The price of a unit is a function of the components of this bundle, including a housing unit's size, attribute quality and locational characteristics (DiPasquale \& Wheaton, 1996). Hedonic regression models are commonly used to isolate the underlying equilibrium price for each housing attribute (Allen, Springer, \& Waller, 1995; Sirmans, Macpherson, \& Zietz, 2005; Witte, Sumka, \& Erekson, 1979). The availability of on-site garage parking is one such factor in a household's housing purchase or rental decision, and it is the primary explanatory variable of interest in this study. Economic theory does not specify the housing characteristics which should be incorporated in a hedonic regression model (Edmonds, 1984; Sirmans et al., 2005). As such, there is considerable variation in the explanatory variables other scholars have included in their models. Categories of characteristics generally include structural quality, indoor amenities, external features, natural environmental features, neighborhood and location, public services,

\footnotetext{
${ }^{1}$ Surface parking, on the other hand, is generally provided in areas where the opportunity cost of not building housing is lower.
} 
selling factors and financing issues (Sirmans et al., 2005). We selected variables based on a combination of theory (Sirmans et al., 2005) and other hedonic model specifications using AHS data (Downes \& Zabel, 2002; Glaeser \& Gyourko, 2003; Kiel \& Zabel, 1997; Thibodeau, 1995).

In addition to the garage parking variable described above, we include unit characteristic variables related to size and indoor amenities. A bedrooms variable reflects the number of full bedrooms in a housing unit, and a bathrooms variable captures the number of full bathrooms in the unit. These are two of the most commonly used variables in hedonic models (Sirmans et al., 2005). We expect each additional bedroom and bathroom to add to the rental price. We use four indicator variables representing common apartment amenities that represent unit quality: central air-conditioning, a dishwasher, in-unit laundry, and a fireplace. We also include a variable representing building age, measured by the number of years since the building was constructed. We expect units in newer buildings to be more expensive. Because the relationship between building age and price is generally non-linear due to depreciation and vintage effects (Goodman \& Thibodeau, 1995), we also include building age squared in our models.

A drawback of recent changes in the AHS public use file is the lack of variables with which to measure neighborhood characteristics (Kiel \& Zabel, 1997). Ideally we would include a measure of neighborhood housing density, but since that is unavailable in the public use file, we use the height of the building as a proxy for neighborhood density. That is, we expect that a unit in a 20-story building is more likely to be in a denser neighborhood than a unit in a 2-story building, and we expect higher rents in more dense areas due to the cost of land. For neighborhood quality, we follow Thibodeau (1995) and use respondents' self-reported neighborhood opinion rating. Like Glaeser and Gyourko (2003), we add an indicator variable reflecting Central City location to reflect relative location within a given metropolitan area. 
Lastly, since we are using a national sample and there is great inter-metropolitan variation in the built environment and economic conditions, we control for metropolitan population density and median income in $2010 .^{2}$ We expect rents to be higher in denser and higher-income metropolitan areas.

We specify two hedonic regression models to isolate the relationship between garage parking and rent, ceteris paribus. Again, we focus on the role of garage spaces because they are more expensive to construct and are more likely to be built in urban areas with relatively high land costs. Our hedonic regression models are shown in equations 1 and 2 below.

\section{Equation 1}

Rent $=\mathrm{a}+\mathrm{b}_{1}$ Garage Parking $\mathrm{i}_{\mathrm{i}}+\mathrm{b}_{2}$ Controls $_{\mathrm{i}}+\mathrm{e}_{\mathrm{i}}$

\section{Equation 2 \\ $\ln ($ Rent $)=a+b_{1}$ Garage Parking ${ }_{i}+b_{2}$ Controls $_{i}+e_{i}$}

where the dependent variable is a household's annual rent (Equation 1) or the natural log of annual rent (Equation 2); garage parking is an indicator variable with a value of one if a housing unit has at least one garage or carport parking space on-site included in the cost of rent; the controls are a vector of neighborhood and metropolitan variables, and an error term expresses the residual of each equation. As a robustness test to ensure that our results were not driven by

\footnotetext{
${ }^{2}$ We aggregate county-level data from the 2010 American Community Survey to the 1980 standard metropolitan statistical areas (SMSA) definitions used in the 2011 American Housing Survey.
} 
metropolitan level factors, we also ran the models with standard errors clustered by Standard Metropolitan Statistical Area (SMSA), of which there were 147 in the sample.

We use equations 1 and 2 to model the entire urban rental sample, a sub-sample of recent movers, and a sub-sample of carless renters. We use the entire urban rental sample to estimate the overall cost effects of garage parking across all rental units. We use the sub-sample of recent movers as a robustness check because additional neighborhood quality variables are available for housing units occupied by recent movers in the AHS. ${ }^{3}$ Lastly, we estimate the spending on garage parking by carless renters. We use this last value to estimate the direct deadweight loss borne by renters who do not have an automobile, but are nevertheless paying for a garage parking space. We calculate deadweight loss by multiplying the coefficient for garage parking from the carless renter sub-sample by the number of carless renters living in units with a garage by the sample weight to make the estimate nationally representative.

\section{Results}

We first characterize bundled parking and vehicle ownership. We then report descriptive statistics and bivariate correlations between annual rent and each individual unit characteristic, neighborhood attribute, and metropolitan independent variable. Finally, we present the results of the hedonic regression models.

\footnotetext{
${ }^{3}$ Specifically, the survey asks new movers whether they moved to their current residence because of the quality of neighborhood factors including schools, public services, transit, and general appearance. Data on these additional neighborhood variables is available for a limited set of urban rental households $(n=13,677)$. We include these variables in the same model as above with a more limited sample.
} 


\section{Bundled parking and renters without vehicles}

A large majority ( $83 \%)$ of the units in the sample included some kind of parking on-site. About $38 \%$ of rental units had garage parking while $45 \%$ of the units had surface or other nongarage parking spaces. About $17 \%$ of the urban rental units in the survey did not have a parking space, and this ranged dramatically by metropolitan area. The New York City area had the highest prevalence of units without parking (73\%), contrasting sharply with Orange County, California at the other extreme (1\%). Across metros, there were approximately 3.5 million rental units without parking. These units tended to be smaller, older and with fewer in-unit amenities than units with bundled parking.

Most American households have at least one automobile; nationwide only about $7.1 \%$ of rental households do not have a car (United States Census Bureau, 2011). As with bundled parking, there is considerable inter-metropolitan variation in the share of households without a vehicle, from $26 \%$ in metropolitan New York City to $1.5 \%$ in the St. George (Utah) metropolitan area. Across the entire 2011 AHS sample - which includes renter and owner-occupied units more than $29 \%$ of households without a car do not live in a housing unit with a bundled parking space, as opposed to less than $4 \%$ of households with a vehicle. Within our final sample of renter-occupied units, these percentages are $27 \%$ and $7 \%$ respectively. Quantifying the relationship between vehicle ownership and parking is important because carless households are paying for something that they most likely do not need or want. For instance, studies find evidence of substantial under-utilization of garage spaces in multi-family residential buildings across multiple West Coast metropolitan areas (Cervero, Adkins, \& Sullivan, 2010; Rowe, Bae, $\&$ Shen, 2010; Willson, 2015). While resale or subleasing of spaces undoubtedly occurs, there is little empirical evidence about its prevalence, or the degree to which households use their private 
garage spaces for non-parking uses, like storage or a work space. Anecdotally, it seems that storage is the most common non-parking use of a private garage (Arnold, Graesch, Ragazzini, \& Ochs, 2012; Consumer Reports, 2015). This practice is less likely in structured parking garages. The prevalence and nature of alternative uses of parking space is worthy of future research, and it would help us to refine estimates of deadweight loss.

\section{The American rental housing stock}

The average yearly rent in the sample was approximately $\$ 10,951$, or $\$ 913 /$ month, with a standard deviation of $\$ 478{ }^{4}$ The amenities of air-conditioning, laundry and dishwashers were each present in about half of the rental housing in the sample. Fireplaces were a feature of only $15 \%$ of the rental units. The mean rental unit had about two bedrooms and more than one bathroom. The average unit was constructed nearly fifty years ago, but well into the post-war period with ubiquitous parking requirements (Shoup, 2005). The average rental unit in the sample was situated in a three-story building, reflecting a mix of single-family, low-rise apartments and high-rise apartment building types. About 59\% of rental units were in the central city of their respective metropolitan areas; the rest were in core urban areas outside the central city or in smaller suburban jurisdictions. The average renter in the survey assessed their neighbourhood quality as an 8 on a 10 point scale, with 10 being the most favorable assessment.

\footnotetext{
${ }^{4}$ All in 2011\$. The AHS top-codes rental values at the $99.5^{\text {th }}$ percentile, so we would expect these averages to be marginally higher in the absence of top-coding. However, this does not represent a concern for the integrity of the analysis, as we are most interested in parking's effect on low- and moderate-cost rental housing, rather than the high end of the rental market.
} 


\section{Bivariate results}

The bivariate correlations between each of the independent variables and annual rent mostly show expected relationships (Table 1). Our primary variable of interest, garage parking, is positively associated with unit rent. The variables for unit size and quality are all positively associated with rent, with the exception of central air-conditioning, which has a very small negative coefficient. Newer units are generally more expensive than older ones. Units in higherrise buildings tend to be less expensive, which may be capturing the difference between singlefamily and multi-family rental housing. Units in neighborhoods that are more highly rated by residents are associated with higher rents. Lastly, units in denser and higher income metropolitan areas tend to be more expensive, as expected.

[Insert Table 1 about here]

\section{Hedonic regression results}

Again, we use hedonic regression techniques to examine the relationship between garage parking and housing rents while holding other unit, neighborhood, and metropolitan factors constant. We report coefficients and robust standard errors for each of two model specifications (Table 2). Model 1 coefficients can be interpreted in terms of the dollar value they comprise of rent. A one-unit change in Model 2 coefficients is associated with 100 times the coefficient percentage change in rent. In both models, the distribution of the dependent variable approximates the normal curve.

[Insert Table 2 about here] 
As shown in Table 1, the substantive results of the two specifications are quite similar. The statistical significance and the direction of the relationship between the independent variables and garage parking is identical across models, except for building height. The two models, however, provide different information regarding the value of garage parking as a factor in rental price. Model 1 shows that a parking garage spot costs about $\$ 1,700$ per year, or $\$ 142$ per month. Model 2 suggests that the addition of a parking space increases the price of rent by around $17 \%$. Both models show that the cost of a garage space represents a substantial share of a household's rent payment. ${ }^{5}$

In terms of importance in the model, metro effects of density and income have the greatest impacts on prevailing rent prices, and building age is the most influential building characteristic or unit characteristic. Building height - our proxy for density - is not significantly associated with rent levels, but residents' self-assessment of neighbourhood quality is associated with higher monthly rent. Unit size - measured in terms of the number of bedrooms and bathrooms - is positively associated with rents, as expected. The unit amenities of fireplaces and dishwashers are also associated with higher rents, while the laundry and central air-conditioning variables have no significant relationship with rent.

In a hedonic regression on the sub-sample of units occupied by carless renters (results not shown), we find that garage parking costs an average of $\$ 621$ a year or a $13 \%$ premium on their rental price. We calculate the deadweight loss to society stemming from garage parking provided

\footnotetext{
${ }^{5}$ The substantive result of our modelling was unchanged by employing a clustered standard error approach. Although coefficients are reduced and confidence intervals are increased in this specification, the statistical significance and sign of the relationships between individual attributes and rental value are consistent, including the value of garage parking. This gives us further confidence that metropolitan level effects, although important, are not driving the model results.
} 
by landlords to residents of 708,000 housing units who do not own a car. At a national level, this deadweight loss amounts to $\$ 440$ million paid for garage parking spaces unused by residents for parking annually. This amount only represents the direct cost of parking requirements on lowincome renters, and does not account for the many indirect costs of parking provision (Shoup, 2005). ${ }^{6}$

\section{Discussion}

Our results support the economic logic that an apartment with garage parking, ceteris paribus, will be more expensive than one with surface parking or no parking. This logic is rooted in demand and supply side factors. On the demand side, garage parking spaces are a valuable amenity for urban renters. Garage parking offers cover from the elements, which reduces external wear to a vehicle, and guarantees convenience and time saved for the consumer. Garage parking is particularly valuable in higher-density urban neighborhoods where on-street parking is metered or difficult to procure. Carless households, and households who do not use their garage for automobile parking, may still gain some utility from a garage by using it for storage or even additional living space. This would be more likely for households with a private one or two-car garage, rather than a household with a designated space in a shared parking structure or underground parking garage.

On the supply side, the direct and indirect costs of parking provision are high, and these costs are passed on to renters. Garage parking is expensive to build and its provision often represents a substantial opportunity cost for a real estate developer. Above-ground parking also

\footnotetext{
${ }^{6}$ We lack data on the prevalence of renters sub-leasing their parking spaces, but even if a small share of renters do rent out their garage parking, the amount of wasted resources is substantial.
} 
represents an opportunity cost since land area is devoted to parking rather than leasable residential or commercial space. We show that these direct and indirect costs are passed on to consumers in the form of higher rents. Again, garage parking is associated with higher rents of about $\$ 142$ per month or a $17 \%$ premium for urban residents. When assessing the price of garage parking, these figures are conservative because they include some carports, which would presumably command a smaller price premium. Our study presents the first national findings which quantify the relationship between parking and housing costs.

While the ubiquity of parking provision reflects a combination of misguided regulation and household demand, the provision of parking supply without associated demand can only be characterized as wasteful. We are concerned about the social equity dimensions of parking provisions, and we quantify the extent of this loss nationally for urban renters. We find that there is a large deadweight loss associated with renters paying for garage parking that they do not use for car storage, which we estimate to be about $\$ 440$ million dollars per year. Given that the carless population in the U.S. is generally lower-income than the car-owning population, many of the households involuntarily paying for garage parking are the ones that can least afford to do so. In fact, we find that households which have a garage space but no car have only a little more than half of the income $(\$ 24,000)$ of other households $(\$ 44,000)$. In the absence of paying for an unused parking space, these rent outlays could be applied to renting a larger or better-located unit, other consumer spending, or saving for a home purchase. The deadweight loss associated with carless households has not been quantified previously in the literature.Future research can further assess the indirect costs of bundled parking provision on households and society more broadly. 
Our primary policy recommendation is for cities to ease or eliminate minimum parking requirements in urban areas. This is a pressing recommendation because even if parking requirements were relaxed today, as is being implemented in some cities, the housing stock is durable and the housing supply take years to adjust to demand for new bundles of housing attributes (DiPasquale \& Wheaton, 1996). It would likely take a decade or two before consumers could choose from a wider selection of housing options with unbundled parking. Reducing or eliminating minimum parking requirements would have the biggest benefits to renters in higherdensity, centrally-located neighborhoods where garage parking is prevalent.

Our second policy recommendation, which supplements the first, is that cities allow or encourage real estate developers to unbundle parking from new housing. Again, this recommendation depends on reform of minimum parking standards. If minimum parking standards are not reduced or eliminated, a developer would have little or no incentive to unbundle parking because there would be an oversupply of parking that could not be rented, and a developer would essentially pay for this. A combination of policies would allow real estate developers to build with less parking, and then to use pricing to allocate the parking spaces that are constructed however they see fit. Real estate developers could then better respond to demand from consumers who are currently or prospectively carless. But, there are enough unanswered questions about parking bundling to prevent us from recommending that cities require unbundled parking, as has been the approach of San Francisco (City of San Francisco, 2013) and downtown Cleveland (Willson, 2015). We need to learn more about how real estate developers price unbundled parking, and the degree to which some parking-related costs could still be passed along to those who do not rent a parking space. Relatedly, it would be useful to assess how secondary markets for parking spaces in private structures would function most efficiently. 
Moreover, the potential regulatory barriers to such markets must be better understood, along with measures taken to address legitimate security concerns that might arise from landlords or building tenants to sharing parking spaces with non-tenants.

There are two potential limitations to our analysis. First, some of the price premium associated with garage parking may be attributable to unobservable characteristics associated with garage parking which are not captured in our model; this is an inherent limitation of a hedonic modeling approach. To ensure that our estimate of parking cost was not overly sensitive to our final model specification, we tested the inclusion of other collinear independent variables. We did not find that the inclusion of these variables substantially lowered our estimate of garage space price in the main model. Second, there are a limited number of exogenous neighborhood attribute variables available for the entire sample due to limitations in reporting in the AHS dataset. Consequently, in our main models, we use several proxies and self-reported variables to represent neighborhood characteristics. In a smaller sub-sample of recent movers, we find that only school quality is a significant factor in rental value and that the inclusion of other neighborhood variables does not substantially alter the rent estimates from our more expansive sample. Particularly, the estimated impact of garage parking on rental value is virtually identical to the full sample. This gives us confidence that the inclusion of additional neighborhood attributes would not substantially change our findings.

\section{Conclusion}

In this study, we examine the effects of bundled parking provision on metropolitan residential rents. We focus on renters in urban areas because these households are experiencing the worst housing cost burdens. Our findings provide the first nationally representative evidence 
that urban garage parking provision is very costly to renters. We provide further evidence that minimum parking requirements are burdensome to renters and lead to societal waste. Carless households, including many lower-income households, in neighborhoods where garage parking is the norm are disproportionately affected. Eliminating minimum parking requirements in these locations would allow the market to gradually meet the latent demand for housing options with unbundled parking, would reduce the annual $\$ 440$ million deadweight loss directly experienced by urban renters without cars, and would partially remedy the perverse incentive for driving and sprawling urban form that these requirements have induced over the past seventy-five years. 


\section{Acknowledgments}

We thank the UCLA Ziman Center for Real Estate Howard and Irene Levine Program in Housing and Social Responsibility for generously funding this research. We are grateful to Randy Crane for many interesting discussions about the American Housing Survey and parking policy. We also thank Donald Shoup, Michael Manville, and attendees of the 2015 Association of Collegiate Schools of Planning conference for their insightful comments on previous versions of this study. 


\section{References}

Allen, M. T., Springer, T. M., \& Waller, N. G. (1995). Implicit pricing across residential rental submarkets. The Journal of Real Estate Finance and Economics, 11(2), 137-151. http://doi.org/10.1007/BF01098658

Arnold, J. E., Graesch, A., Ragazzini, E., \& Ochs, E. (2012). Life at home in the twenty-first century: 32 families open their doors. Cotsen Institute of Archaeology Press.

Cervero, R., Adkins, A., \& Sullivan, C. (2010). Are suburban TODs over-parked? Journal of Public Transportation, 13(2). http://doi.org/http://dx.doi.org/10.5038/2375-0901.13.2.3

Chester, M., Fraser, A., Matute, J., Flower, C., \& Pendyala, R. (2015). Parking Infrastructure: A Constraint on or Opportunity for Urban Redevelopment? A Study of Los Angeles County Parking Supply and Growth. Journal of the American Planning Association, 81(4), 268286. http://doi.org/10.1080/01944363.2015.1092879

City of Los Angeles. (2013). Cornfield Arroyo Seco specific plan. Los Angeles Department of City Planning.

City of San Francisco. (2013, September 6). San Francisco Planning Code. City of San Francisco. Retrieved from http://www.amlegal.com/nxt/gateway.dll?f=templates\&fn=default.htm\&vid=amlegal:san francisco_ca

Consumer Reports. (2015, June 11). 10 ways to take back your garage: How to stash your stuff and have room for your cars, too. Consumer Reports. Retrieved from http://www.consumerreports.org/cro/magazine/2015/05/10-ways-to-take-back-yourgarage/index.htm 
Cutter, W. B., \& Franco, S. F. (2012). Do parking requirements significantly increase the area dedicated to parking? A test of the effect of parking requirements values in Los Angeles County. Transportation Research Part A: Policy and Practice, 46(6), 901-925. http://doi.org/10.1016/j.tra.2012.02.012

Deakin, E. (1989). Growth controls and growth management: A summary and review of empirical research. In Understanding growth management: Critical issues and a research agenda. Washington, DC: Urban Land Institute.

DiPasquale, D., \& Wheaton, W. C. (1996). Urban economics and real estate markets. Englewood Cliffs, N.J: Prentice Hall.

Downes, T. A., \& Zabel, J. E. (2002). The impact of school characteristics on house prices: Chicago 1987-1991. Journal of Urban Economics, 52(1), 1-25.

Econometrica, Inc. (2013). Codebook for the American Housing Survey, Public Use File, $1997-$ 2011. Washington, DC: U.S. Department of Housing \& Urban Development, Office of Policy Development. Retrieved from http://www.huduser.org/datasets/ahs/AHS_Codebook.pdf

Edmonds, R. G. (1984). A theoretical basis for hedonic regression: A research primer. Real Estate Economics, 12(1), 72-85.

Farris, J. T. (2001). The barriers to using urban infill development to achieve smart growth. Housing Policy Debate, 12(1), 1-30. http://doi.org/10.1080/10511482.2001.9521395 Gabbe, C. J. (2016). Why are regulations adopted and what do they do? An analysis of land use regulation near major transit in Los Angeles (Doctoral Dissertation). University of California, Los Angeles. 
Glaeser, E. L., \& Gyourko, J. (2003). The impact of building restrictions on housing affordability. New York, N.Y: FRBNY Economic Policy Review. Retrieved from http://app.ny.frb.org/research/epr/03v09n2/0306glae.pdf

Glaeser, E. L., Gyourko, J., \& Saks, R. (2005). Why have housing prices gone up? (Working Paper No. 11129). Cambridge, MA: National Bureau of Economic Research. Retrieved from http://www.nber.org/papers/w11129

Goodman, A. C., \& Thibodeau, T. G. (1995). Age-related heteroskedasticity in hedonic house price equations. Journal of Housing Research, 6(1), 25-42.

Jia, W., \& Wachs, M. (1999). Parking Requirements and Housing Affordability: Case Study of San Francisco. Transportation Research Record: Journal of the Transportation Research Board, 1685(-1), 156-160. http://doi.org/10.3141/1685-20

Joint Center for Housing Studies. (2015). The State of the Nation's Housing 2015. Cambridge, MA: Harvard University. Retrieved from http://www.jchs.harvard.edu/research/state_nations_housing

Kain, J. F., \& Quigley, J. M. (1975). Housing Markets and Racial Discrimination: A Microeconomic Analysis. NBER. Retrieved from http://www.nber.org/books/kain75-1

Kennedy, P. (1995). An Infill Developer Versus the Force of No. Urban Ecologist, (2).

Kiel, K. A., \& Zabel, J. E. (1997). Evaluating the usefulness of the American housing survey for creating house price indices. The Journal of Real Estate Finance and Economics, 14(12), 189-202.

Landis, J. D., Hood, H., Li, G., Rogers, T., \& Warren, C. (2006). The future of infill housing in California: Opportunities, potential, and feasibility. Housing Policy Debate, 17(4), 681725. http://doi.org/10.1080/10511482.2006.9521587 
Levine, N. (1999). The effects of local growth controls on regional housing production and population redistribution in California. Urban Studies, 36(12), 2047-2068. http://doi.org/10.1080/0042098992539

Li, F., \& Guo, Z. (2014). Do parking standards matter? Evaluating the London parking reform with a matched-pair approach. Transportation Research Part A: Policy and Practice, 67, 352-365. http://doi.org/10.1016/j.tra.2014.08.001

Manville, M. ((in press)). Bundled parking and vehicle ownership: Evidence from the American Housing Survey. Journal of Transport and Land Use.

Manville, M. (2013). Parking requirements and housing development. Journal of the American Planning Association, 79(1), 49-66. http://doi.org/10.1080/01944363.2013.785346

Manville, M., Beata, A., \& Shoup, D. (2013). Turning housing into driving: Parking requirements and density in Los Angeles and New York. Housing Policy Debate, 23(2), 350-375. http://doi.org/10.1080/10511482.2013.767851

McDonnell, S., Madar, J., \& Been, V. (2011). Minimum parking requirements and housing affordability in New York City. Housing Policy Debate, 21(1), 45-68. http://doi.org/10.1080/10511482.2011.534386

Millard-Ball, A. (2002). Putting on their parking caps. Planning. April, 2002, 16-21.

Quigley, J. M., \& Raphael, S. (2005). Regulation and the high cost of housing in California. The American Economic Review, 95(2), 323-328.

Rowe, D. H., Bae, C.-H. C., \& Shen, Q. (2010). Assessing multifamily residential parking demand and transit service. ITE Journal, 80(12). Retrieved from http://search.proquest.com/openview/4524c5e0680c7f4c8dc0c903e8361471/1?pqorigsite $=$ gscholar 
Shoup, D. (2005). The High Cost of Free Parking. Chicago, IL: Planners Press, American Planning Association.

Shoup, D. (2014). The High Cost of Minimum Parking Requirements. In C. Mulley \& S. Ison (Eds.), Parking: Issues and Policies (pp. 87-113). Emerald Group Publishing.

Sirmans, S., Macpherson, D., \& Zietz, E. (2005). The Composition of Hedonic Pricing Models. Journal of Real Estate Literature, 13(1), 1-44. http://doi.org/10.5555/reli.13.1.j03673877172w0w2

Thibodeau, T. G. (1995). House price indices from the 1984-1992 MSA American housing surveys. Journal of Housing Research, 6, 439-482.

United States Census Bureau. (2011). 2011 American Community Survey 1-year estimates.

Willson, R. W. (1995). Suburban Parking Requirements: A Tacit Policy for Automobile Use and Sprawl. Journal of the American Planning Association, 61(1), 29-42. http://doi.org/10.1080/01944369508975617

Willson, R. W. (2015). Parking management for smart growth. Washington, DC: Island Press. Retrieved from https://books.google.com/books?hl=en\&lr=\&id=k7fkCQAAQBAJ\&oi=fnd\&pg=PR2\&d $\mathrm{q}=$ Parking + Management + for + Smart + Growth\&ots $=$ BRjBxlZqeL\&sig=Wbf9KNIbi0ApY_DfNzsHziBowA

Witte, A. D., Sumka, H. J., \& Erekson, H. (1979). An estimate of a structural hedonic price model of the housing market: an application of Rosen's theory of implicit markets. Econometrica: Journal of the Econometric Society, 1151-1173. 


\section{Tables}

\section{Table 1: Descriptive Statistics and Bivariate Correlations}

Variable
Average

$\$ 10,951$

NA

Parking characteristics

Garage parking space(s)

Other unit and building characteristics

Number of bedrooms

Number of full bathrooms

Central air-conditioning

Fireplace

Dishwasher

Laundry

Age of building (years)

Neighborhood characteristics

\section{Outcome of interest}

Annual rent

s)

$38 \%$

$0.37 * * *$

1.95

1.25

$50 \%$

$15 \%$

$50 \%$

$47 \%$

49
$0.30 * * *$

$0.27 * * *$

$0.37 * * *$

$-0.01 *$

$0.17 * * *$

$0.09 * * *$
$0.29 * * *$
Correlation to yearly rent 
Number of floors in building

Self-assessed neighbourhood rating (1-

10,10 being highest)

Location in central city of metropolitan

area

Metropolitan area characteristics

Population density (persons/square

mile

Median income

$*$ p-value $<.10, * *$ p-value $<.05, * * *$ p-value $<.01$
3.0

$-0.04 * * *$

7.56

$0.12 * * *$

$59 \%$

$-0.06 * * *$

1,907

$0.22 * * *$

$\$ 58,079$

$0.43 * * *$

Table 1: Hedonic regression results on annual rent

\begin{tabular}{|c|c|c|}
\hline Variable Name & $\begin{array}{c}\text { Model 1: } \\
\text { Coefficient } \\
\text { (robust } \\
\text { standard error) }\end{array}$ & $\begin{array}{c}\text { Model 2: } \\
\text { Coefficient } \\
\text { (robust standard } \\
\text { error) }\end{array}$ \\
\hline \multicolumn{3}{|c|}{ Parking characteristics } \\
\hline Garage parking & $\begin{array}{c}\text { \$1699*** } \\
(95)\end{array}$ & $\begin{array}{c}.17 * * * \\
(.01)\end{array}$ \\
\hline
\end{tabular}




\begin{tabular}{|c|c|c|}
\hline \multicolumn{3}{|l|}{ Other unit and building characteristics } \\
\hline Number of bedrooms & $\begin{array}{c}739 * * * \\
(87)\end{array}$ & $\begin{array}{l}.06^{* * *} \\
(.01)\end{array}$ \\
\hline Number of bathrooms & $\begin{array}{c}1811^{* * *} \\
(290)\end{array}$ & $\begin{array}{l}.14^{* * *} \\
(.02)\end{array}$ \\
\hline Central air-conditioning & $\begin{array}{l}-156 \\
(111)\end{array}$ & $\begin{array}{l}-.02 \\
(.01)\end{array}$ \\
\hline Fireplace & $\begin{array}{l}950^{* * *} \\
(150)\end{array}$ & $\begin{array}{l}.07 * * * \\
(.01)\end{array}$ \\
\hline Dishwasher & $\begin{array}{c}2097 * * * \\
(118)\end{array}$ & $\begin{array}{l}.24 * * * \\
(.01)\end{array}$ \\
\hline Laundry & $\begin{array}{l}-76 \\
(106)\end{array}$ & $\begin{array}{l}-.01 \\
(.01)\end{array}$ \\
\hline Building age & $\begin{array}{l}-50^{* * *} \\
(8.39)\end{array}$ & $\begin{array}{c}-.005 * * * \\
(.001)\end{array}$ \\
\hline Building age squared & $\begin{array}{l}.56^{* * *} \\
(.08)\end{array}$ & $\begin{array}{c}.000 * * * \\
(.000)\end{array}$ \\
\hline Neighborhood characteristics & & \\
\hline Number of floors in building & $\begin{array}{l}41 \\
(26)\end{array}$ & $\begin{array}{l}-.01 * * \\
(.002)\end{array}$ \\
\hline $\begin{array}{l}\text { Self-assessed neighbourhood rating ( } 1 \text { - } \\
10,10 \text { being highest) }\end{array}$ & $\begin{array}{c}227 * * * \\
(21)\end{array}$ & $\begin{array}{l}.02 * * * \\
(.002)\end{array}$ \\
\hline $\begin{array}{l}\text { Location in central city of metropolitan } \\
\text { area }\end{array}$ & $\begin{array}{l}80 \\
(88)\end{array}$ & $\begin{array}{l}-.01 \\
(.01)\end{array}$ \\
\hline
\end{tabular}




\begin{tabular}{|l|c|c|}
\hline \multicolumn{2}{|l|}{ Metropolitan area characteristics } \\
\hline Population density (persons/sq km) & $643^{* * *}$ & $.06^{* * *}$ \\
& $(30)$ & $(.002)$ \\
\hline Median income (000) & $168^{* * *}$ & $.02^{* * *}$ \\
& $(5.1)$ & $(.000)$ \\
\hline Constant & -6589 & 7.69 \\
& $(512)$ & $(.05)$ \\
\hline Model statistics & $\mathrm{N}=38,662$ & $\mathrm{~N}=38,662$ \\
& Prob $>\mathrm{F}=0.000$ & Prob $>\mathrm{F}=0.000$ \\
& Adjusted R- & Adjusted R- \\
& Squared $=0.34$ & Squared $=0.28$ \\
\hline
\end{tabular}

